\title{
ROLE OF COMPOST AND IRRIGATION WATER QUANTITY ON SOME PHYSICAL PROPERTIES OF SOIL UNDER SURFACE, SUBSURFACE DRIP IRRIGATION
}
M. F. Al-Shamari*
B. A. A. H. Alkhateb*
S. A.W. Mahmoud**
* Dept. Soil and Water Resource, Coll. Agric, University of Anbar, Iraq. ** Dept. Hortic, Coll. Agric. University of Anbar, Iraq.
marwafarhood92@gmail.com

ABSTRACT

A field experiment was conducted in Ramadi district - Al-Anbar province during the autumn season of 2018. to study the role of compost (sheep residues) and irrigation levels in some physical properties of soil and water consumption a potato under surface and subsurface drip irrigation system. Randomized Complete Block Design (RCBD) in arrangement of a splitsplit-plot with three replication were used.The results showed that the addition of $10 \mathrm{Mg} . h^{-1}$ resulted in a significant decrease in bulk density (BD) values of $1.12 \mathrm{Mg} \mathrm{m}^{-3}$, and increase in the values of (MWD) and (Ks) to reach $1.47 \mathrm{~mm}$ and $10.3 \mathrm{~cm} . \mathrm{hr}^{-1}$ respectively. The addition of $50 \%$ of the NID reduced the BD to $1.24 \mathrm{Mg} \mathrm{m}^{-3}$, The MWD and SHC were significantly higher to reach $1.24 \mathrm{~mm}$ and $8.1 \mathrm{~cm} \mathrm{hr}^{-1}$ respectively. WHC increased with increasing of amount of irrigation water as it reached the highest value of $265.66 \mathrm{~mm}$ season ${ }^{-1}$ when adding $100 \%$ of the NID. The BD values decreased, whereas MWD and SWC increased under subsurface irrigation (SUBDI) treatment to be $1.23 \mathrm{Mg} \mathrm{m}^{-3}, 1.24 \mathrm{~mm}$ and $8.4 \mathrm{~cm} \mathrm{hr}^{-1}$, respectively.

Keywords: Compost; Drip Irrigation; water Quantity

$$
\begin{aligned}
& \text { مجلة العلوم الزراعية العراقية -2020 :51 (5):1307-1300) الثمري وآخرون } \\
& \text { دور الكمبوست وكمية مياه الري في بعض الخصائص الفيزيائية تحت نظام الري بالتنقيط السطحي وتحت السطحي }
\end{aligned}
$$

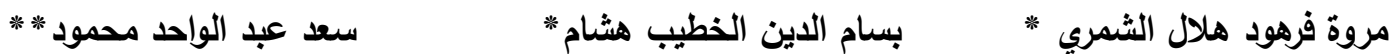

$$
\begin{aligned}
& \text { كلية الزراعة / جامعة الانبار }
\end{aligned}
$$

المستخلص

نفذت تجرية حقلية في قضاء الرمادي - محافظة الانبار خلال الموسم الخريفي 2018، لاراسة دور الكمبوست ومستويات الري

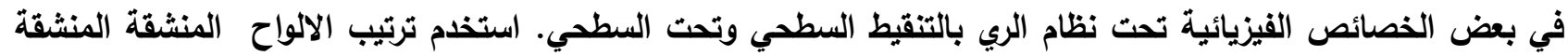

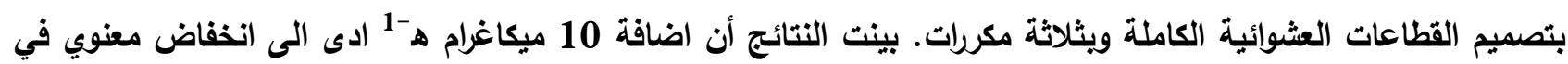

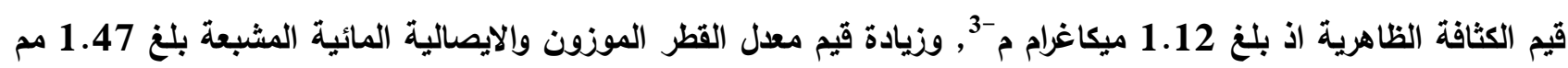

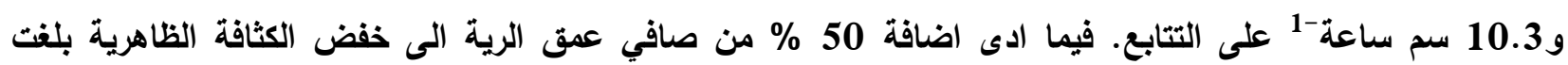

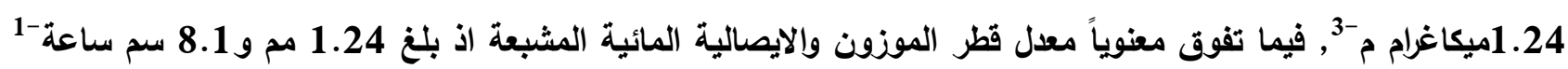

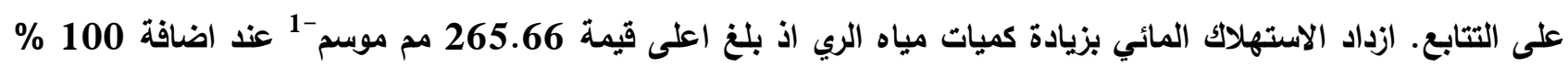
من صافي عمق الرية. كما انخفضت قيم الكثافة الظاهرية وازداد معدل قطر الموزون والايصالية المائية المشبعة عند معاملة المائة

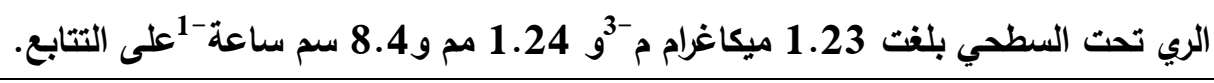
كلمات مفتاحيه: الكمبوست، مستوى الري، ري بالتتقيط 


\section{INTRODUCTION}

The soil organic fertilizers of various sources have a positive important role in the improvement of soil physical properties, increasing water-holding capacity, improvement of porosity, permeability, and bioactivity. Its role is to stabilize the soil particles with each other, increase the soil water infiltration, reduce surface runoff and improve crop growth by improving soil structure. The values of porosity increase to reduce bulk density, which facilitates plant roots penetration in soil profile (1). Many studies have tried to find different methods in programming irrigation operations by controlling the quantities of added irrigation water, and scheduling the addition using modern irrigation methods, especially in areas of limited water because of limited water resources and losing large quantities of them during conventional irrigation operations. Surface and subsurface drip irrigation systems are the most important of these techniques, which are one of the most efficient irrigation systems because this system provides water to the plant at the perimeter of the root zone (Rhizosphere) during different stages of plant growth(17). The addition of manure at different levels 0,30 and 60 tons. $\mathrm{ha}^{-1}$ in a silty clay soil resulted in a significant superiority in the values of mean weight diameter, which increased from 0.34 to 0.40 and $0.75 \mathrm{~mm}$ it also increased hydraulic conductivity from 6.48 to 14.07 and $14.62 \mathrm{~cm} \cdot \mathrm{hr}^{-1}$ (18). The addition of manure at a of 10 tons. $\mathrm{h}^{-1}$ caused the lowest value of bulk density which is 1.14 Mg.m-3 while the 1.25 and $1.33 \mathrm{Mg} \mathrm{m}^{-3}$ when adding 5 tons.h- ${ }^{1}$ without the addition of organic fertilizer respectively attributing the reason to the ability of organic fertilizers to improve soil structure through increased porosity, the stability of soil aggregate increased pore percentage, and movement of water and air in the soil. Increased levels of deficit drip irrigation was also resulted in nonsignificant difference in bulk density values, where it was $1.24 \mathrm{Mg} \cdot \mathrm{m}^{-3}$ in irrigation treatment of $100 \%$ in comparison with $50 \%$ and $75 \%$ levels which were 1.24 and $1.23 \mathrm{Mg} \cdot \mathrm{m}^{-3}$ with an increase of 0 and $0.8 \%$ respectively (3). The bulk density values increased significantly with increasing water stress ratios, which reached $1.40,1.38$ and 1.34 $\mathrm{Mgm} . \mathrm{m}^{-3}$ at the exhaustion treatment of $40 \%$ of the available water, and reached 1.42, 1.39, and1.26 Mg.m ${ }^{-3}$ at deficit treatment50\% of available water, while the highest values were 1.43, 1.41 and $1.38 \mathrm{Mg} . \mathrm{m}^{-3}$ at the depletion treatment of $60 \%$ of the available water for the full and half and triple additions consecutively (4). The object of this study is investigating the role of compost manure and irrigation levels under surface and subsurface drip irrigation system and some physical soil properties.

\section{MATERIALS AND METHODS}

A field experiment was conducted at Albo Farraj region - Ramadi district in province of Anbar western of Iraq, in a Silty Loam texture soil during fall season of 2018. The soil class is Typic Torrifluvent subgroup according to US Taxonomy system (21). The field was totally sampled to $(0-30) \mathrm{cm}$ depth randomly and some physical, chemical, and properties were measured in them. Particles size distribution was measured using pipette and hydrometer methods. Bulk density measured by metal core sampler according to (7). The volumetric moisture content of soil was measured at ( $33,300, \mathrm{KPa})$ using Pressure plate membrane. Saturated hydraulic conductivity (SHC) determined by consant water head method (12) in(Table1) Chemical properties of soil were measured in saturated soil past according to (14). Analysis of irrigation water, which has been used in this experiment, illustrated in (Table2).Experiment was carried out at $\left(300 \mathrm{~m}^{2}\right) 12 \times 25 \mathrm{~m}$ area. The experimental land soil tilled by two orthogonal ploughs by the mouldboard plough, softened, and levelled. The field was totally divided to three blocks of $(2 \times 25) \mathrm{m}^{2}$ with $2 \mathrm{~m}$ spaces among blocks. Experimental factors were distributed in split-split plots at randomized complete block design (RCBD) of three replicates. Each block divided into two main plots for two compost levels $(0,10 \mathrm{Mgm})$ and each one subdivided into two sub-plot .The two irrigation methods (surface and subsurface) were distributed into subplots. The spaces between each two plots were 1.5 meters. Each subplot was then divided into three terraces as experimental units in which irrigation levels of $50 \%, 75 \%$ and $100 \%$ of the 
NID were distributed. The drip irrigation system was evaluated at pressures of 40, 50 and $60 \mathrm{kPa}$ to select the best operating pressure that can be adopted during the growing season and according to the uniformity coefficient of water distribution(UC), the discharge variation (DV). The UC was $96.60 \%$ and the lowest variance between points was $10.20 \%$.The surface and subsurface drip irrigation system was utilized T-Tape drips. The US evaporation pan class A was considered in irrigation time determination Actual water consumption (ETa) equivalent to the added water depth (d) and the timing of irrigation were calculated according to the following equations. The volumetric soil moisture (VSM) at irrigation time determined like mentioned in (2)

$$
\boldsymbol{\Theta}_{\mathrm{wi}}=\boldsymbol{\Theta}_{\mathrm{F} . \mathrm{C}}-\left(\boldsymbol{\Theta}_{\text {A.w }} * \mathrm{dp}\right) \text {. }
$$

Where $\boldsymbol{\theta w i}$ is VSM at irrigation time (\%), dp is moisture depletion ratio, $\boldsymbol{\Theta}_{\text {F.C }}$ is VSM at field capacity $(\%)$.

Water depth added to soil (d) computed by:

$$
\boldsymbol{d}=\frac{\theta \text { F.C }-\theta \cdot \mathbf{W i}}{\mathbf{1 0 0}} * \mathrm{D}
$$

Where $d$ is water depth added to soil $(\mathrm{cm}), D$ is active Rhizosphere (cm).

Reference evapotranspiration $\left(\mathrm{Et}_{0}\right)$ computed by (2) equation:

$$
\begin{aligned}
& \mathbf{E t}_{\mathbf{0}}=\text { ETa } \\
& \text { Kc }
\end{aligned}
$$

Where $\mathbf{E T}_{\mathbf{0}}$, ETa, and $\mathbf{K}_{\mathbf{c}}$ are the reference evapotranspiration, actual evapotranspiration $\left(\mathrm{mm} . \mathrm{day}^{-1}\right)$, and crop factor respectively.The $(0.8,0.75,1.15$, and 0.8$)$ values in (19) were considered as a representative for vegetative growth, tubers formation, tubers swelling, and maturity stages respectively. Irrigation schedule timed according the value of $E_{p a n}$, which is equivalent to exhaustion ratio in equation (3) as follows:

$\mathrm{E}_{\text {pan }}=\frac{E T 0}{K p}$

Where, Epan is the evaporation measured in

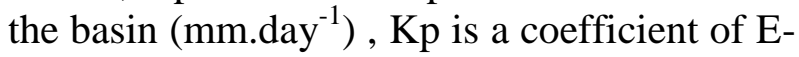
pan, Water quantity added to soil as a leaching requirement, which was $6 \%$, calculated according to (9) equation that concerned the modern systems irrigation like drip irrigation as follows:

$L R=\frac{E C i w}{2(M A X E C e)} \times 100$

$\mathrm{LR}$ is Leaching Requirement (\%), $\mathrm{EC}_{\mathrm{iw}}$ is Electrical Conductivity of Irrigation Water (20 $\left.\mathrm{dS} . \mathrm{m}^{-1}\right), \mathrm{MAX}_{\mathrm{ECe}}$ is the Maximum EC (dS.m $\left.{ }^{1}\right)$. These percentage values units converted to water depth units of irrigation according to (7) which is:

$\mathbf{d}_{\mathbf{L}}=\mathbf{L R} * \mathbf{d}$

$\mathrm{d}_{\mathrm{L}}$ is Leaching Requirement Depth ( $\left.\mathrm{mm}\right), \mathrm{d}$ is Irrigation Water Depth required $(\mathrm{cm})$. The total water depth (irrigation + leaching requirement water) that must be added to soil estimated in eq. 7

TDI $=\frac{d+d_{L}}{E i}$

Where TDI is Total Irrigation Depth; $d_{L}$ is Leaching Requirement depth, $\mathrm{E}_{\mathrm{i}}$ is Efficiency of drip irrigation, which was $85 \%$ in this study.Irrigation time estimated according to (2) equation:

$\mathbf{q} * \mathbf{t}=\mathbf{a} * \mathbf{d}$

Where $\mathrm{q}$ is applied quantity discharge $\left(\mathrm{m}^{3} \mathrm{~h}^{-1}\right)$; $\mathrm{t}$ is Time of irrigation (hour); $\mathrm{a}$ is Area of

\begin{tabular}{|c|c|c|c|c|c|c|}
\hline Property & Quantity & Units & \multicolumn{2}{|c|}{ Property } & Quantity & Units \\
\hline Sand & 420 & \multirow{4}{*}{$\mathrm{g} \mathrm{kg}^{-1}$} & \multicolumn{2}{|c|}{ pH } & 8.0 & - \\
\hline Silty & 506 & & \multicolumn{2}{|c|}{$\mathbf{E C}_{\mathrm{e}}$} & 3.0 & $\mathrm{dS} \mathrm{m}^{-1}$ \\
\hline Clay & 74 & & & $\mathrm{Ca}^{2+}$ & 22.50 & \\
\hline Texture & Silt Loam & & Positive & $\mathbf{M g}^{2+}$ & 12.50 & \\
\hline Bulk density & 1.32 & $\operatorname{Mg~m}^{-3}$ & Dissolved & $\mathrm{Na}^{+}$ & 7.30 & \\
\hline hydraulic conductivity & 4.28 & cm hour ${ }^{-1}$ & Anion & $\mathbf{K}^{+}$ & 0.13 & \\
\hline 33 & 35.60 & & & $\mathrm{SO}_{4}{ }^{2}$ & 8.06 & $\operatorname{meq} \mathrm{l}^{-1}$ \\
\hline 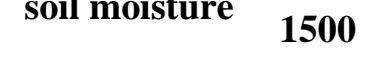 & 10.20 & 0 & & HCO & 2.00 & \\
\hline $\begin{array}{c}\text { available water } \\
\mathrm{CaSO}_{4} \\
\mathrm{CaCO}_{3}\end{array}$ & $\begin{array}{c}25.30 \\
3.5 \\
165.0\end{array}$ & $\mathrm{~g} \mathrm{~kg}^{-1}$ & $\begin{array}{c}\text { Dissolved } \\
\text { Anion }\end{array}$ & $\mathrm{CO}_{3}^{2-}$ & $\begin{array}{l}\text { Nill } \\
9.0\end{array}$ & \\
\hline
\end{tabular}
witting circle for dripper $\left(\mathrm{m}^{2}\right) \mathrm{d}$ is the Depth of added water $(\mathrm{m})$.

Table1.Physical and chemical properties of the soil 
Table 2.chemical properties of irrigation water

\begin{tabular}{|c|c|c|c|c|c|c|c|c|c|c|c|c|}
\hline \multirow{2}{*}{$\begin{array}{c}E C \\
\text { dS m }{ }^{-1}\end{array}$} & \multirow{2}{*}{ pH } & \multicolumn{8}{|c|}{ Anion Dissolved meq $\mathrm{l}^{-1}$} & \multirow{2}{*}{$\begin{array}{l}\mathrm{NO}_{3}= \\
\mathrm{Ppm}\end{array}$} & \multirow{2}{*}{ SAR } & \multirow{2}{*}{ Class } \\
\hline & & $\mathrm{Ca}^{+2}$ & $\mathrm{Mg}^{+2}$ & $\mathrm{Na}^{+}$ & $\mathbf{K}^{+}$ & $\mathrm{Cl}^{-}$ & $\mathrm{SO}_{4}^{-2}$ & $\mathrm{HCO}_{3}^{-}$ & $\mathrm{CO}_{3}=$ & & & \\
\hline 1.25 & 7.5 & 1.21 & 4.1 & 4.94 & 0.24 & 4.0 & \begin{tabular}{|l|}
5.4 \\
\end{tabular} & 2.0 & $\begin{array}{l}0.0 \\
\end{array}$ & 2.10 & 2.4 & $\mathrm{C}_{3} \mathrm{~S}_{1}$ \\
\hline
\end{tabular}

RESULTS AND DISCUSSION water inside soil pores and decrease porosity

\section{Bulk densist (BD)}

Fig.1. Shows the effects of different factors on BD values.BD values decreased by $35 \%$ and $22.3 \%$ at the addition of 0 and $10 \mathrm{Mgm}^{-1} \mathrm{~h}^{-1}$ of compost levels respectively compared to the same values before cultivation (Table1), as a result to soil structure improvement due to manure addition by increasing soil porosity, aggregates stability and also increasing units of soil volume respectively(6). Surface and subsurface drip irrigation systems have significant effects on $\mathrm{BD}$ values as shown in Fig.1.BD value was decreased under SUBDI to $1.23 \mathrm{Mgm} . \mathrm{M}^{-3}$ where it reached 1.33 under SDI which can be contributed to the lack of wetting-drying cycles because of availability of sufficient amounts of water that cause movements of fine particles with percolated due to compaction of soil under ordinary surface irrigation style (11 and 13). Increasing irrigation levels, as shown in Fig.1 caused significant differences in BD values where its value was $1.31 \mathrm{Mg} \cdot \mathrm{m}^{-3}$ under $100 \%$ irrigation treatment compared to 1.27 and $1.24 \mathrm{Mg}^{-} \mathrm{M}^{-}$ ${ }^{3}$ for $75 \%$ and $50 \%$ of the NID, the increasing percentage was $1 \%$ and $6 \%$ for each on respectively. The later may be caused by differentiation of water quantity that give a chance for suitable water reservation for a long period, lack of wetting-drying cycles between irrigation terms, soil structure improvement, and increasing soil porosity and this emphasize that rapid wetting-drying periods, swelling of soil were the cause of structure's deterioration (4).

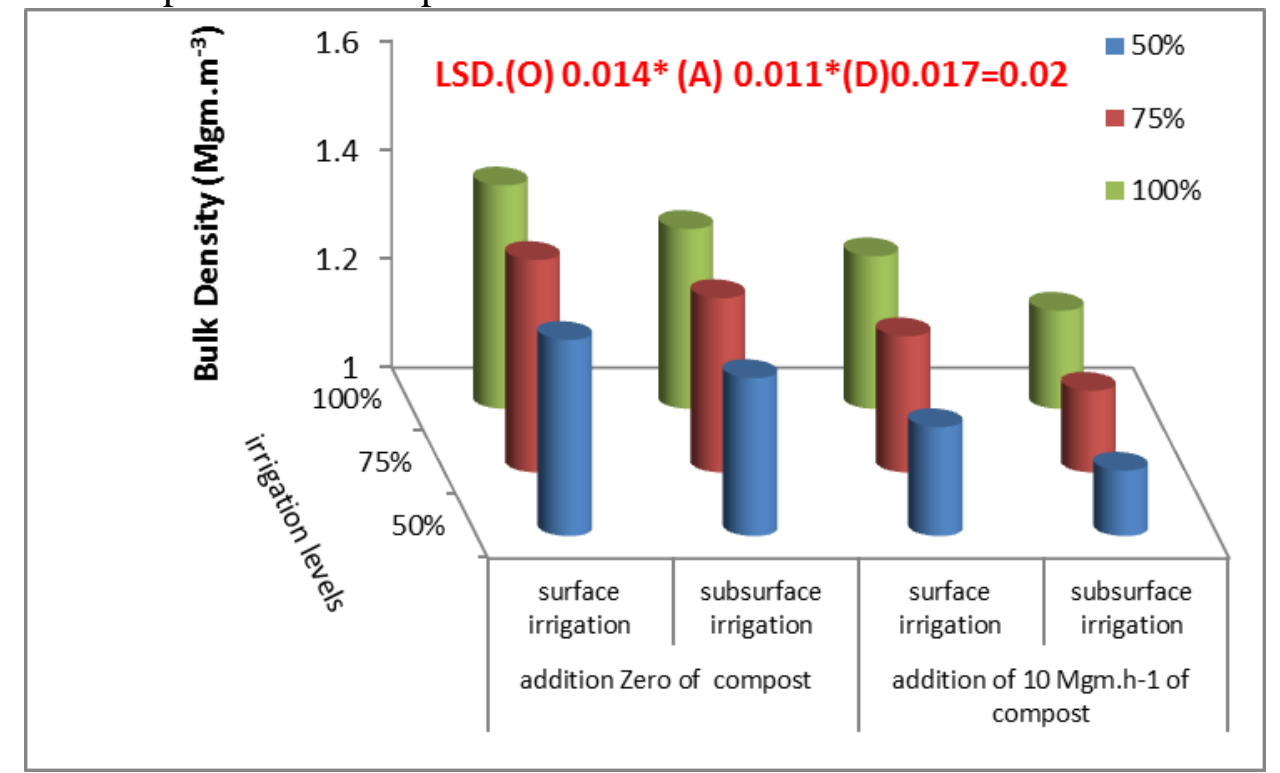

Figure 1. Effects of treatments on soil Bulk Density $\left(\mathrm{Mgm} \mathrm{m}^{-1}\right)$

\section{Mean weight diameter (WMD)}

Fig. 2. illustrates the highest value of MWD $(1.47 \mathrm{~mm})$ as a result of $10 \mathrm{Mgm} \cdot \mathrm{ha}^{-1}$ of compost addition in comparison with $0.76 \mathrm{~mm}$ for zero addition, this can be attributed to increasing aggregates' stability and formation of cementing agents due to decomposition of compost by soil microbes as a result of organic acids formation (like Humic, Fulvic, ... etc), surface encasement of soil particles to reduce their moistening rapidity (18). Fig. 2. also shows significant effects of SDI and SUBDI $n$
MWD values. The SUBDI systems cause a significance in crane MWD value of $1.24 \mathrm{~mm}$ for MDW in comparison with $0.98 \mathrm{~mm}$ for SDI . This result may be because the role of SUBDI in conserving soil moisture in sufficient amount for different stages of plant growth at the Rhizosphere region, this is consistent with (10). Increasing irrigation levels caused significant differences in MWD values (Fig.2).Generally, the MDW decreased significantly with increasing irrigation levels, where the least value was $0.95 \mathrm{~mm}$ in $100 \%$ of 
the net irrigation depth (NID), Similarly, MWD values were 1.14 and $1.24 \mathrm{~mm}$ for $75 \%$ and $50 \%$ for NIDs respectively. The reason of decreasing in MWD values with the increase in irrigation levels is the destruction of soil aggregates, which leads to the deposition of fine particles between the pores, which led to an increase in the values of soil BD, which reflected on the stability of soil aggregates (3).

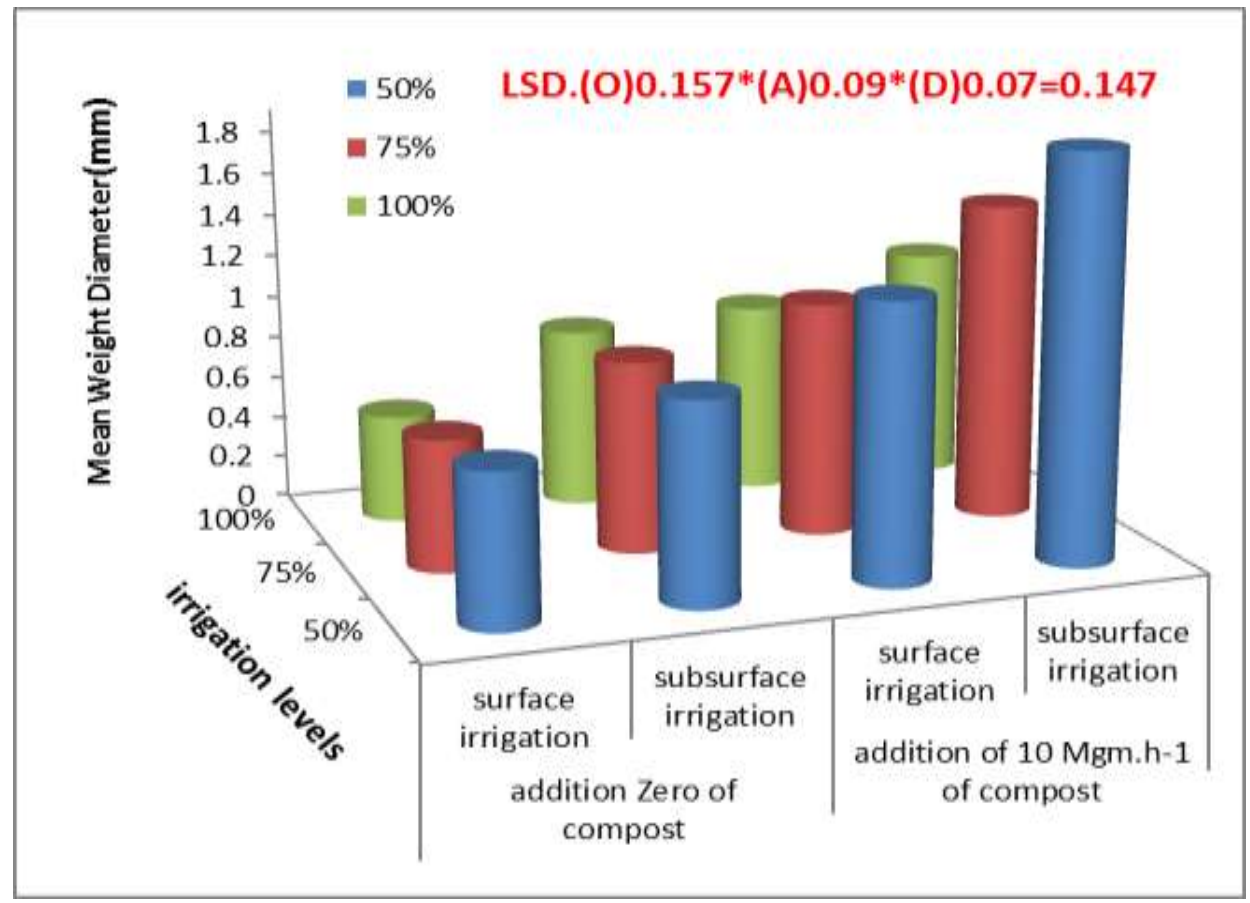

Figure 2. Effects of treatments on MWD (mm)

\section{Saturated hydraulic conductivity (Ks)}

Fig.3. Shows Effects of treatments on SHC values. The SHC values were increased in comparison with their pre-cultivation values, which were 5.2 and $10.4 \mathrm{~cm} . \mathrm{hr}^{-1}$ at the level 0and 10 Mg.ha ${ }^{-1}$ of compost additions respectively compared to their values after cultivation (Table.1), this increasing values of SHC contributed to increase cementing agents with increase compost levels, which connect soil particles (8).The same figure shows effects of SDI and SUBDI on SHC. There was a significant increase in SHC values to reach $8.4,6.9 \mathrm{~cm} . \mathrm{hr}^{-1}$ for SUBDI and SDI respectively, and this can be attributed to the direct impact of SDI in destruction of aggregates at water entrance to soil and explosion of reserved air bubbles to smash those aggregates. Furthermore may be because of wetting-drying circles among irrigations, or the erosive power of moving on wetting front, which cause partial movement of fine particles through water percolation, which clog pore spaces and rise BD value that reflects on soil's
$\mathrm{HC}$ (3). The effects of irrigation levels on SHC were illustrated in Fig.3. a negative relationship can be observed among them, where SHC value was $7.2-\mathrm{cm}$. hour ${ }^{-1}$ at $100 \%$ level and increased respectively to $7.7,8.1 \mathrm{~cm}$. hour $^{-1}$ for $75 \%$ and $50 \%$ sequences. This inversely relationship may be because of drying-wetting operation consequences that cause dispersion and separation of soil particles to deposit in pore-spaces and clog them to form impermeable layers of high $\mathrm{BD}$, which cause less downward water moving in also because of irrigation frequency (20). The interference among factors on SHC mean values can be concluded from Fig.3. There was a significant increase in SHC value to be $10.3 \mathrm{~cm}$. hr ${ }^{-1}$ at addition of 10 Ton.ha $^{-1}$ of compost level under 50\% NID of SUBDI, this increasing SHC was agreed with(5) attributions to the effect of organic fertilizers and SUBDI on soil structure improvement as a result to MWD increase that decrease values of BD. 


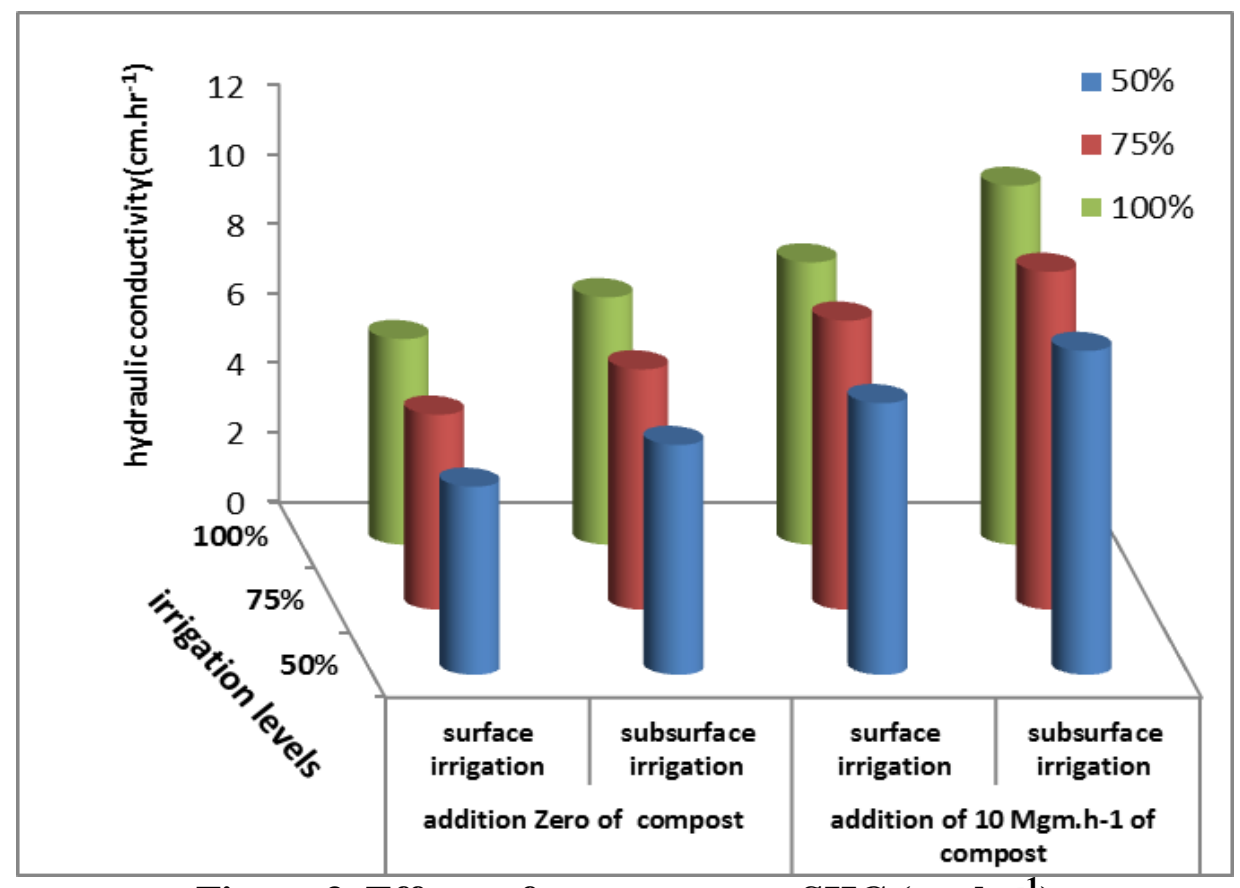

Figure 3. Effects of treatments on SHC $\left(\mathrm{cm}^{-\mathrm{hr}^{-1}}\right)$

Mean of Water Consumptive Use (WCU) irrigations' number was reduced with (mm.season ${ }^{-1}$ )

Table.3 Shows WCU values of potatoes at different growth stages, it is observed that applied depths irrigation water increased successively with growth stages to reach $88.55,66.43$, and $44.28 \mathrm{~mm}$ for irrigation levels $100 \%, 75 \%$, and $50 \%$ of NID respectively due to increasing depth of roots' extension in soil with plant age progress, roots' expansion was also increase soil volume, Furthermore, the intense need of plants to water and available nutrients in these two stages for bioactivities, tissues, and cells especially in stage of tubers swelling. The reason of decreased WCU at the end of growth season was attributed to the sufficiency of plant tissues, cells, and the degrease of bioactivity, which cause in WCU (11). The progression of growth stages where the highest irrigations' number was 10 at pre-germination stage and 1 irrigation at maturity stage; this decrease was due to time of each growth stage where the longest period was 30 days at pregermination stage. Table 3. Shows that actual WCU values were 293.41, 223.97, and 154.25 $\mathrm{mm}$ for irrigation levels $100 \%, 75 \%$, and $50 \%$ of NID respectively. The same table shows positive relationship between water saving ratio (WSR) and irrigation levels ratio (ILR). The ILR of $50 \%$ and $75 \%$ of NID treatments saved 580.25 and $406.01 \mathrm{~m}^{3}$ of WSR compared to ILR of $100 \%$, these water volumes can be invested in other areas that equivalent to 3.75 and 3.34 Ton.ha $^{-1}$ of total yield. 
Table 3 . Effect of irrigation levels in depths and volumes of added water

\begin{tabular}{|c|c|c|c|c|c|c|c|}
\hline Stage & $\begin{array}{l}\text { Duration } \\
\text { Of stage } \\
\text { (Day) }\end{array}$ & $\begin{array}{c}\text { Irrigatio } \\
\mathbf{n} \\
\text { levels }\end{array}$ & $\begin{array}{c}\text { Roots } \\
\text { depth } \\
\text { (cm) }\end{array}$ & $\begin{array}{c}\text { Required } \\
\text { Water } \\
\text { Depth }\end{array}$ & $\begin{array}{l}\text { Leaching } \\
\text { Requiremen } \\
\text { t Depth } \\
\text { Im ) }\end{array}$ & $\begin{array}{c}\text { Number } \\
\text { of } \\
\text { irrigations }\end{array}$ & $\begin{array}{c}\text { Irrigation } \\
\text { Requirement } \\
\mathbf{M}^{3} \cdot \text { ha }^{-1}\end{array}$ \\
\hline $\begin{array}{c}\text { Growth } \\
\text { Stage }\end{array}$ & 30 & $\% 40$ & 15 & 15.10 & 0.94 & 10 & 944.43 \\
\hline $\begin{array}{c}\text { Vegetative } \\
\text { Growth } \\
\text { Stage }\end{array}$ & 12 & $\begin{array}{c}\% 50 \\
\% 75 \\
\% 100\end{array}$ & 20 & $\begin{array}{l}25.30 \\
37.96 \\
50.61\end{array}$ & $\begin{array}{l}1.51 \\
2.27 \\
3.03\end{array}$ & 3 & $\begin{array}{l}115.06 \\
161.22 \\
230.13\end{array}$ \\
\hline \multirow{3}{*}{$\begin{array}{c}\text { Tuber } \\
\text { Initiation } \\
\text { Stage }\end{array}$} & \multirow{3}{*}{17} & $\% 50$ & & 31.62 & 1.89 & & 142.44 \\
\hline & & $\% 75$ & 26 & 47.45 & 2.84 & 3 & 187.89 \\
\hline & & $\% 100$ & & 63.25 & 3.79 & & 284.88 \\
\hline \multirow{3}{*}{$\begin{array}{c}\text { Tuber } \\
\text { Bulcking } \\
\text { Stage }\end{array}$} & \multirow{3}{*}{17} & $\% 50$ & & 37.95 & 2.27 & & 246.34 \\
\hline & & $\begin{array}{c}\% 75 \\
\% 100\end{array}$ & 33 & $\begin{array}{l}56.94 \\
75.90\end{array}$ & $\begin{array}{l}3.41 \\
4.55\end{array}$ & 2 & $\begin{array}{l}311.12 \\
493.34\end{array}$ \\
\hline & & $\% 50$ & & 44.28 & 2.65 & & 76.34 \\
\hline \multirow[t]{2}{*}{$\begin{array}{l}\text { Maturation } \\
\text { Stage }\end{array}$} & 7 & $\% 75$ & 39 & 66.43 & 3.98 & 1 & 94.78 \\
\hline & & $\% 100$ & & 88.55 & 5.31 & & 152.67 \\
\hline \multirow{2}{*}{\multicolumn{2}{|c|}{ Total }} & $\% 50$ & & 146.71 & 9.26 & 19 & 1524.94 \\
\hline & & $\% 75$ & - & 223.97 & 13.44 & 19 & 1699.44 \\
\hline
\end{tabular}

\section{REFERENCES}

1. Abdul Hamza, J. B. and J. I. Al - Hadithi. 2013. Effect of organic matter sources and levels on some physical soil properties and yellow maize yield (Zea mays L). Qadisiyah Journal of Pure Sciences. (15)123-131

2. AlHadith|.A. K, A. M.AL, and, Y. K. Hamza.2010.Modern irrigation technologies and other issues in the water issue book.

3. ALJanabi,M.A and A. Fares.2012. Effect of drip irrigation, organic fertilization and coverage on potato growth and yield (Solanum tuberosum L.).ph.D.College of Agriculture, University of Baghdad

4. Al-Khatib, B. A .H . and E. M.H. AlShaabani, 2017. Directory of open access journals outils webmaster Some Growth and Potential Characteristics of Potatoes under Humidity Drain and Irrigation Management in Desert Soil in Western Iraq. Anbar Journal of Agricultural Sciences 15 (13): 122-136

5. Allen, R.G.; Pereira, L.S.; Smith, M.; Raes, D.; Wright, J.L. Fao-56 dual crop coefficient method for estimating evaporation from soil and application extensions. J. Irrig. Drain. Eng. 2005, 131, 213

6. Ati, A. S. R. M. Shihab, S. A. Aziz. and F. H. Ahmed, 2010. Production and water use of potato under regulated deficit irrigation treatments . Annals, Agric .Sci. Ain Shams Univ, Cairo, 55(1), 123-128

7. Black, C. A. 1965. Methods of Soil Analysis. Am. Soc. Agron. No(.9)Part1.Madison,Wisconsn. USA. pp. 374 $-390$

8. Dianqing , L. S ; Mongon ; H. Robert ; and L. chunping. 2004. Effect of Changing bulk density during water desorption measure mention soil hydraulic properties. Soil Sci. 169. $5: 319-329$

9. Dorota Z. Haman. 2000. Irrigation with high salinity water. Florida. Cooperative Extension service, Institute of food an agricultural sciences, University of Florida.drainage. Paper No.29. FAO publication, Rome

10. Dulaimi. S. I. H.. and A.W. A. Albed 2011. Effect of drip irrigation and drip irrigation on some physical properties of soil, tomato growth and yield. Anbar Journal of Agricultural Sciences 9 (13): 146-156 
11. Irmak, S. 2005. A Brief Research Update on Subsurface Drip Irrigation. Dept. of Bio. System engineering, University of Nebraska Lincoln,USA

12. Klute,A.1965.Laboratorymeasurement of hydraulic conductivity of saturated soil. In Black , C.A. et al., (eds). Method of soil analysis. Agron. Mono. No. Amer. Soc., Agron. Madison, Wisconsin, USA. . 9 (1) : 253-261

13. Lamm, F.M.2002.Advantages and Disadvantages of Subsurface Drip Irrigation. International Meeting on Advantage in Drip/Micro Irrigation. Puerto de La Cruz, Tenerife, Canary Islands

14. Sahoki, M, K.and M. Waheeb 1990. Applications in Experimental Design and Analysis, Ministry of Higher Education and Scientific Research, House of Wisdom for Printing and Publishing, University of Baghdad, Republic of Iraq

15. Saleh. M.A. and R. M. Shihab.2014. Effect of deficit irrigation and mulching on consumptive use and yield of potato in gypsiferous soil under drip irrigation.14(3) . 37-49
16. Sarhan, A. H. M.. 2009. Effect of irrigation schedules under drip irrigation system on moisture and salt distribution in salineaffected soils.m.se Thesis. College of Agriculture .University of Baghdad

17. Shirani,H;M.A. Hajabbasi;M. Afyuni and A. Hemmat .2002. Effects of farmyard manure and tillage systems on soil physical properties and corn yield in central Iran. Soil \& Tillage Research 68 :101-108

18. Shiri-e-Janagrad, M. A. Tobeh, S. Hokmalipour, Jamaati-e-Somarin Sh. A; Abbaasi, and K. Shahbazi. 2009. Potato Response to driirrigation regimes and plant arrangements during growth periods. Asian J. of Plant Sciences. V (8). Issue: 6 P: 390-399 19. Shock, c. c. Piereira, A. B., Hanson, B. R. and Chan, M. D. 2007.Vegetable irrigation. In: Lascano and Sojka (eds.), Irrigation of Agricultural Crop.. Agron. Monograph 30 and ed. ASA, CSSA, SSSA, Ma: WI, USA. P. 535606

20. USDA . "Keys to Soil Taxonomy" Eleventh Edition . 2010. Natural Resources Conservation Service. (NRCS). 